\section{Prevalence and risk factors associated with Campylobacter among layer farms}

\author{
Mohammad Q. Al-Natour, ${ }^{1}$ \\ Akram R. Al-Aboudi, ${ }^{1}$ \\ Musa A. Alshehabat, ${ }^{2}$ MT K. Tamimi1 \\ 1Department of Veterinary Pathology \\ and Public Health; ${ }^{2}$ Department of \\ Veterinary Clinical Sciences, Faculty of \\ Veterinary Medicine, Jordan University \\ of Science and Technology, Irbid, \\ Jordan
}

\begin{abstract}
Campylobacter jejuni is an important food-borne pathogen. The main source of this pathogen is poultry and poultry products. Poultry farms of low biosecurity level plays major role in disseminating this pathogen. The objectives of this study were to investigate the occurrence of
\end{abstract} Campylobacter and identify potential risk factors associated with their presence in layer farms in Northern Jordan. A total of 2524 samples from chickens, litter, water and feed were collected from 35-layer farms. Samples underwent conventional and enrichment isolation methods for Campylobacter. Confirmation was done morphologically, biochemically and by PCR typing. The flock-level prevalence of C. jejuni was $40 \%, 37 \%, 20 \%$ in chicken cloacae, drinking water and litter respectively. C. jejuni was the only confirmed isolated species. None of the feed samples revealed presence of Campylobacter. The concentration of free residual chlorine was below the recommended standard levels. The risk factors were identified using modified semi-structured questionnaire. There was no significant association between evaluated risk factors and isolation status potentially reflecting small number of study farms. The prevalence rate for $C$. jejuni is within commonly reported range. High stocking density, short distance between farms, improper hygienic practice and low water chlorine level seems to increase occurrence rate of Campylobacter in layer farms. Educational biosecurity programs regarding $C$. jejuni transmission and their public health importance needs to be established.

\section{Introduction}

Campylobacter organisms are gram negative spiral-shaped bacteria which inhabit the intestine of many species and can cause clinical manifestation of variable severity. ${ }^{1}$ Campylobacter is considered of great public health significance worldwide because it is the most reported gastrointestinal bacterial foodborne pathogen. ${ }^{2}$ Most commonly reported human illnesses are caused by Campylobacter jejuni. ${ }^{2}$ In the United States, there have been reports of more new 2 million Campylobacter cases per year. ${ }^{3}$ In European Union, nearly 200,000 cases have been reported in 2009.4

The Campylobacter organism seems to be adapted to birds which they carry without being or showing signs of illness. It has been reported that most people becoming ill with Campylobacter manifest a variety of clinical signs including potentially bloody diarrhea, vomiting, nausea, abdominal pain, and fever within few days after exposure to the organism and typically signs lasts for few days. 5 Small percentage of infected people do not express clinical signs however Campylobacter can potentially cause more serious and life threatening clinical signs in people with compromised immune system. ${ }^{6}$ It has been reported that $50-70 \%$ cases of human Campylobacter is attributed to consuming contaminated poultry products. This reflects the need for lowering contamination associated with Campylobacter thus decreasing occurrence which is considered essential step in lowering incidence rate of human infection. In many countries, culled layer chicken is consumed as part of human diet.7 In Jordan, layer chickens are sold as spent hens for human consumption at the end of their laying period. There have been a considerable research body that documented and characterized the prevalence and risk factors associated with Campylobacter in broiler chicken industry. A local study in Jordan was conducted on samples obtained from broiler birds at the slaughter house indicating a $40 \%$ prevalence rate of Campylobacter ${ }^{8}$ However, there is limited research efforts conducted to estimate the occurrence rate and identify risk factors associated with Campylobacter in layer industry. Therefore, the broad goal of the research project reported here is to determine prevalence of Campylobacter, source of infection and risk factors associated with Campylobacter infection in layer flocks in Northern Jordan.

\section{Materials and Methods}

\section{Sample collection and analysis}

Cloaca, litter, water, and feed samples
Correspondence: Mohammad Q. Al-Natour, Department of Veterinary Pathology and Public Health, Faculty of Veterinary Medicine, Jordan University of Science and Technology, Irbid, Jordan.

Tel.: +962.2.7201000 - Ext.22063/22064.

E-mail: alnatour@just.edu.jo

Key words: Campylobacter, Layer chicken, Jordan.

Contributions: MQAN, made substantial contributions to the design and execution of the study, participated in the manuscript's drafting; ARAA, made contributions to the design of the study, participated in the manuscript's drafting and executed the bacteriogical isolation; MAA, participated significantly in the manuscript's drafting and executed the statistical analysis; MTKT, contributed to the design of the study and participated in laboratory work.

Conflict of interest: the authors declare no conflict of interest.

Funding: This work was support by the Jordan University of Science and Technology Deanship of Research project number 244/2010

Received for publication: 24 January 2016. Accepted for publication: 28 July 2016.

This work is licensed under a Creative Commons Attribution NonCommercial 4.0 License (CC BY-NC 4.0).

CC Copyright M.Q. Al-Natour et al., 2018 Licensee PAGEPress srl, Italy

Veterinary Science Development 2018; 8:6430 doi:10.4081/vsd.2018.6430

were collected from 35 operating layer farms represented by 43 flocks and a total of 478,600 birds located in Northern Jordan. ${ }^{9}$ Each farm/house was visited once, where five cloacal swabs representing 1000 birds were collected (giving a total of 2395 cloacal samples). Sterile swabs were inserted into the cloaca and rotated gently before being pulled out. A total of $500 \mathrm{gm}$ of litter or feed were randomly collected from five different locations from each house/farm and ten different locations water sources (drinkers) were randomly selected to collect a total of pooled 2 litters of water from each house/farm. All cloacal, litter, water, feed samples were harvested utilizing sterile swabs, spoons, containers and gloves then transported to laboratory in an ice box and analyzed within few hours from collection.

Water samples collected from the main water tanks and water drinkers from each farm/house was also analysed to determine 
the level of total chlorine, free residual chlorine and water acidity (water $\mathrm{pH}$ ). Total and free residual chlorine was measured using DPD (N, N-diethyl-p-phenylenediamine) method and results were expressed with range of 0 to 3.5 parts per million (ppm) or equivalent to (0-3.5 $\mathrm{mg} / \mathrm{L})$. Water acidity was measured electrometrically using $\mathrm{pH}$ meter (inoLab, Germany).

\section{Isolation identification and confir- mation of Campylobacter}

The reference bacterial strains used in this study as positive control were $C$. jejuni ATCC 33291 and $C$. coli ATCC 43478 that was obtained from Jordanian Food and Drug Administration.

The method described by ISO 102721:2006(E) was followed for isolation of Campylobacter. ${ }^{10}$ Samples collected from cloaca, litter, feed or filtered water $(0.45$ $\mathrm{mm}$ membrane filter) were separately diluted with $225 \mathrm{~mL}$ of enrichment Bolton broth medium (Oxoid, UK) and homogenized using stomacher (Seaward, U.K) for 2 minutes at $2400 \mathrm{rpm}$. Obtained homogenates were incubated at $37^{\circ} \mathrm{C}$ for $4-6$ hours and then at $41.5^{\circ} \mathrm{C}$ for $44 \mathrm{~h} \pm 4 \mathrm{~h}$ under microaerobic conditions using a gas-generating kit Campygen sachets (Oxoid, UK). After enrichment step, inoculums from each source were inoculated into modified charcoal cefoperazone deoxycholate agar (mCCD agar) (Oxoid, UK) and incubated at $41.5^{\circ} \mathrm{C}$ under micro-aerobic atmosphere and inspected after $44 \mathrm{~h} \pm 4 \mathrm{~h}$. Two colonies, presumed to be Campylobacter, were sub-cultured on a non-selective Columbia blood agar (Oxoid, UK) for purification. Confirmation was done by microscopic examination for morphology and motility followed by oxidase, catalase, DRYSPOT latex agglutination, and Hippurate hydrolysis tests. ${ }^{11}$

All oxidase negative colonies do not require further confirmatory tests. The DRYSPOT latex agglutination test (Oxoid, UK) was performed according to the manufacturer's instructions where the test was considered positive when agglutination noticed within 3 minutes. Hippurate hydrolysis test was done according to standard protocol of the manufacturer's instructions. Hippurate hydrolysis test was considered positive if a dark violet color formed in the testing tubes. The Campylobacter jejuni hydrolyzes Hippurate and gives positive results.

\section{PCR molecular typing}

DNA extraction and PCR technique was performed as described by Nayak et al. (2005) for the amplification of 160bp DNA fragment of the oxidoreductase subunit in the Campylobacter genome. ${ }^{12}$ The pair of primers used for $C$. jejuni: F 5'- CAA ATA AAG TTA GAG GTA GAA TGT-3' and R 5'- GGA TAA GCA CTA GCT AGC TGA T-3' and for C. coli: F 5'- ATG AAA AAA TAT TTA GTT TTT GCA-3' and R 5'- ATT TTA TTA TTT GTA GCA GCG-3' (Alpha DNA, Montreal, Canada) were used to amplify DNA fragment that corresponds to the region of oxidoreductase subunit.

\section{Study area and data collection}

A questioner was purposely designed using close end questions. The questionnaires were filled by state veterinarians dur- ing a field visit. The questions gathered information to reflect farms environmental current situation and preventive practices in use that might increase or decrease the risk of infections.

\section{Statistical analysis}

All statistical analyses were performed using SPSS software (SPSS, version 19.0, SPSS Inc., Chicago, IL, USA). Association between isolation of Campylobacter and potential risk factors were initially screened in a univariable analysis using Chi-square test. Only variables with no Collinearity $(\mathrm{r}<0.60)$ were considered for the univariable analysis. Collinearity was evaluated using non-parametric spearman rank correlation test. Only variable with significant association with Campylobacter were considered for the final multivariable logistic regression model. Variables were forced into the multiple regression models using Enter method. The Hosmer-Lemeshow test was used to evaluate the goodness-of-fit for the developed logistic regression model. The independent student t-test was used to test for differences between negative and positive farms in regard to quantitative variables listed in Table 1. Statistical significance was set at $(\mathrm{P} \leq 0.05)$.

\section{Results}

A total of 535, 13, 7 and 0 isolates were recovered from cloacal swabs, water, litter and feed samples respectively. The number of samples that revealed presumptively identified Campylobacter species using

Table 1. Quantitative statistics for Campylobacter evaluated risk factors.

\begin{tabular}{|c|c|c|c|c|c|c|c|}
\hline Variable & Isolation status & Min & Mean & 25th percentile & $50^{\text {th }}$ percentile & 75th percentile & Max \\
\hline Age (weeks) & $\begin{array}{l}\text { Negative } \\
\text { Positive }\end{array}$ & $\begin{array}{l}32 \\
36\end{array}$ & $\begin{array}{l}52.00 \\
60.00\end{array}$ & $\begin{array}{l}40.00 \\
52.00\end{array}$ & $\begin{array}{l}52.00 \\
64.00\end{array}$ & $\begin{array}{l}64.00 \\
64.00\end{array}$ & $\begin{array}{l}76.00 \\
80.00\end{array}$ \\
\hline Number of birds per farm & $\begin{array}{l}\text { Negative } \\
\text { Positive }\end{array}$ & $\begin{array}{l}5000 \\
3000\end{array}$ & $\begin{array}{l}16414 \\
11847\end{array}$ & $\begin{array}{l}6000 \\
6000\end{array}$ & $\begin{array}{l}17500 \\
11000\end{array}$ & $\begin{array}{l}20000 \\
16000\end{array}$ & $\begin{array}{l}48000 \\
20000\end{array}$ \\
\hline Distance between farms (m) & $\begin{array}{l}\text { Negative } \\
\text { Positive }\end{array}$ & $\begin{array}{c}1000 \\
30\end{array}$ & $\begin{array}{c}2200 \\
380\end{array}$ & $\begin{array}{c}1750 \\
90\end{array}$ & $\begin{array}{c}2000 \\
500\end{array}$ & $\begin{array}{c}3000 \\
500\end{array}$ & $\begin{array}{c}3300 \\
700\end{array}$ \\
\hline Stocking density (birds/m2) & $\begin{array}{l}\text { Negative } \\
\text { Positive }\end{array}$ & $\begin{array}{l}5 \\
9\end{array}$ & $\begin{array}{c}6.04 \\
10.33\end{array}$ & $\begin{array}{c}5.38 \\
10\end{array}$ & $\begin{array}{c}6 \\
10\end{array}$ & $\begin{array}{c}7 \\
11\end{array}$ & $\begin{array}{c}7 \\
12\end{array}$ \\
\hline Water pH (drinkers) & $\begin{array}{l}\text { Negative } \\
\text { Positive }\end{array}$ & $\begin{array}{l}7.14 \\
7.28\end{array}$ & $\begin{array}{l}7.51 \\
7.38\end{array}$ & $\begin{array}{l}7.30 \\
7.30\end{array}$ & $\begin{array}{l}7.60 \\
7.40\end{array}$ & $\begin{array}{l}7.70 \\
7.40\end{array}$ & $\begin{array}{l}7.80 \\
7.65\end{array}$ \\
\hline Total chlorine in main water tanks & $\begin{array}{l}\text { Negative } \\
\text { Positive }\end{array}$ & $\begin{array}{l}0.20 \\
0.20\end{array}$ & $\begin{array}{l}0.28 \\
0.27\end{array}$ & $\begin{array}{l}0.28 \\
0.21\end{array}$ & $\begin{array}{l}0.25 \\
0.26\end{array}$ & $\begin{array}{l}0.37 \\
0.34\end{array}$ & $\begin{array}{l}0.40 \\
0.40\end{array}$ \\
\hline Residual chlorine main water tanks & $\begin{array}{l}\text { Negative } \\
\text { Positive }\end{array}$ & $\begin{array}{l}0.00 \\
0.00\end{array}$ & $\begin{array}{l}0.11 \\
0.09\end{array}$ & $\begin{array}{l}0.04 \\
0.00\end{array}$ & $\begin{array}{l}0.10 \\
0.07\end{array}$ & $\begin{array}{l}0.20 \\
0.20\end{array}$ & $\begin{array}{l}0.20 \\
0.20\end{array}$ \\
\hline Total chlorine in drinkers & $\begin{array}{l}\text { Negative } \\
\text { Positive }\end{array}$ & $\begin{array}{l}0.00 \\
0.01\end{array}$ & $\begin{array}{l}0.78 \\
0.08\end{array}$ & $\begin{array}{l}0.08 \\
0.03\end{array}$ & $\begin{array}{l}0.05 \\
0.06\end{array}$ & $\begin{array}{l}0.16 \\
0.15\end{array}$ & $\begin{array}{l}0.18 \\
0.20\end{array}$ \\
\hline Residual chlorine in drinkers & $\begin{array}{l}\text { Negative } \\
\text { Positive }\end{array}$ & $\begin{array}{l}0.00 \\
0.00\end{array}$ & $\begin{array}{l}0.06 \\
0.02\end{array}$ & $\begin{array}{l}0.00 \\
0.00\end{array}$ & $\begin{array}{l}0.01 \\
0.01\end{array}$ & $\begin{array}{l}0.06 \\
0.06\end{array}$ & $\begin{array}{l}0.07 \\
0.09\end{array}$ \\
\hline
\end{tabular}


Table 2. Number of PCR confirmed Campylobacter jejuni and prevalence rate of positive farms.

\begin{tabular}{lccc} 
Sample source & No. of tested samples & Number of PCR confirmed isolates & $\begin{array}{c}\text { Number and prevalence rate among farms } \\
{[\mathbf{n}=35],(\%)}\end{array}$ \\
Cloaca & 2395 & 535 & $14(40)$ \\
Litter & 43 & 7 & $7(20)$ \\
Water & 43 & 13 & $13(37)$ \\
Feed & 43 & 0 & $0(0)$ \\
\hline Total & 2524 & 555 & $14(40)$ \\
\hline
\end{tabular}

mCCD agar was 978 positive out of the 2524 tested samples. All of the 555 Agglutination positive isolates were positive for both Hippurate hydrolysis test and Catalase test and were also confirmed molecularly using PCR technique as $C$. jejuni (Table 2). Isolation sources of Campylobacter from positive farms are presented in Table 3.

Univariate binary regression analysis showed no significant association between the evaluated risk factors and the isolation of Campylobacter. Also, multiple regression analysis showed no significant association between the isolation of Campylobacter and the evaluated risk factors collectively probably reflecting the small sample size of the study farms. Data are presented in Table 4.

The independent student t-test showed only significant difference between negative and positive cloacal isolates in regard to stocking density, height of the fence, distance between farms and water $\mathrm{pH}$. Summary of data are presented in Tables 1 and 4.

The level of total chlorine in the main water tanks and water troughs of the studied farms ranged from (0.2-0.4 ppm) and (0.0$0.2 \mathrm{ppm})$, while the free residual chlorine ranges were (0-0.2 ppm) and (0-0.09 ppm) respectively (Table 1 ).

The $160 \mathrm{bp}$ product amplified by the primer sets targeting the gene segment on the oxidoreductase encoding gene of all identified $C$. jejuni isolates were detected in all the 555 isolates by conventional PCR.

Our questionnaire reviled 19 Campylobacter positive farms out of the 30 that have no implementation of any hygienic preventive measures. These 30 farms are designated as farms with (Low level of biosecurity). Two Campylobacter positive farms out of the 5 that implement some kind of preventive measures were designated as farms with (Medium level of biosecurity). None of the studies farms have (High level of biosecurity).

Table 3. Sample source and percentages of Campylobacter positive farms $(n=14)$.

\begin{tabular}{lc} 
Sample source & Number and $(\%)$ positive farms \\
Water + cloaca + litter & $2(14)$ \\
Cloaca + water & $3(21)$ \\
\hline Cloaca + litter & $5(36)$ \\
Cloaca only & $4(29)$ \\
Water only & $8(57)$ \\
\hline
\end{tabular}

\section{Discussion and Conclusions}

The prevalence rate of Campylobacter jejuni isolated from the tested farms in cloaca, water, litter and feed was $14 \%, 13 \%, 7 \%$ and $0 \%$ respectively. The $(40 \%)$ flock-level prevalence of $C$. jejuni (cloacal swabs) in the tested layer chicken farms is within the suggested prevalence ranges of $2-100 \%$ in both developed and developing countries. ${ }^{13}$ It is of no difference from other rates detected in broiler chicken from France $(42.7 \%)$, Denmark (42.5\%), Germany (41\%), Japan $(45 \%)$, Italy $(80 \%)$, and Jordan $(40 \%) .8,13$ In this study $C$. jejuni was isolated either from one or different sources within the same farm. The most highly contaminated source of $C$. jejuni was drinking water. Newell et al. (2011) suggesting the horizontal introduction of Campylobacter from the environment in a laying hen flock, which may suggest a link between chicken colonization and water or litter contamination. ${ }^{14}$

In other study of $C$. jejuni rout of transmission and possible sources of infection to broilers, it was concluded that water supply was the predominant source of $C$. jejuni infection on the farm. 15

Positive litter samples were always associated with positive birds. None of the feed samples revealed the presence of Campylobacter and this might be expected because of the dryness of the feed that does not encourage the survival of highly sensitive Campylobacter species. ${ }^{16-18}$

Epidemiological studies characterizing occurrence and risk factors associated with broiler flocks have been widely conducted in many locations. Several risk factors have been reportedly considered significant in the occurrence of Campylobacter in broiler flocks including practicing proper hygienic measures, presence or movement of animals or rodents on the farms or in close proximity, age, and size of the flock. ${ }^{19-25}$ However, epidemiological studies characterizing occurrence and risk factors associated with Campylobacter in layer farms is not fully investigated in many parts of the world. Findings presented here highlight a set of substantial risk factors that could potentially be associated with occurrence of Campylobacter in layer farms.

Univariable or multivariable regression analysis of the evaluated risk factors indicated that there was no statistically significant association between the evaluated risk factors and isolation of Campylobacter which could be mostly attributed to the relatively small number of farms tested. However, analysis of the frequency information and data presented in Tables 1 and 4 indicate some risk factors that are associated with substantially higher prevalence of Campylobacter infection in layer farms. This include birds stocking density $(>6$ birds $\left./ \mathrm{m}^{2}\right)$, short distance between farms $(<1000 \mathrm{~m})$, lack of hand washing before entering the farms, presence of litter piled piles inside the farm, presence of rats, mice, pigeons and sparrows. Furthermore, the mean socking bird density in positive farms was significantly higher (10.33 birds $\left./ \mathrm{m}^{2}\right)$ than negative farms $\left(6.04 \mathrm{birds} / \mathrm{m}^{2}\right)$. Also, the mean distance between positive farms were significantly shorter $(380 \mathrm{~m})$ when compared with negative farms $(2200 \mathrm{~m})$. In here, distance was associated with a decreased risk of Campylobacter infection which might highlight the role of long dis- 
tance for rodents and resident birds. In this study, $60 \%$ of the positive farms had higher bird stocking density and $60 \%$ of positive farms were within short distance to each other. Also, Campylobacter infection was higher on farms that had multiple houses.

Previous epidemiological studies have identified risk factors associated with the prevalence of Campylobacter in broiler farms including higher age of chicken, movement or presence of animals around farms. ${ }^{14-30}$ In here, $5 \%$ of the positive farms had rats or mice while $55 \%$ of the negative farms did have neither rats nor mice. Also, $40 \%$ of the negative farms did not show any pigeons or sparrows. It has been reported that wild birds are potential contaminants to farms or the surrounding soil.31 It appears that good hygiene practices by farmers such as changing disinfectant at gate or house door, decontamination of vehicles entering farms, presence of high fence $(1.8 \mathrm{~m})$ and secure gait, restricted access of non-essential visitors and wearing protective boots seemed to be associated significantly with lower prevalence rate of Campylobacter infection. These findings are in agreement with other previous studies. ${ }^{14,30}$ As expected Campylobacter was isolated from the litter samples which might also act as a potential source of contamination of chicken houses. ${ }^{28,29}$ The potential source of litter contamination is mainly from the intestinal contents and it is expected to survive under its wet condition.

The value of a clean water source is paramount and should be monitored in chicken industry. Chlorine is the most commonly used disinfectant in water treatment of broiler and layer chicken industry. Chlorinating drinking water is helpful in reducing the risk of Campylobacter colonization. ${ }^{26}$ The recommended level of residual chlorine concentration in poultry farms is from 2-5 ppm within a $\mathrm{pH}$ range of 6-8.27 The residual chlorine values recorded in farms under study were less than $2 \mathrm{ppm}$ which is considered not inhibitory for the growth of Campylobacter in chicken drinking water. ${ }^{27}$ Chlorine acts predominantly as

Table 4. Variables included into the final multivariable logistic regression analysis of their association with Campylobacter isolation (data presented as proportions).

\begin{tabular}{|c|c|c|c|}
\hline \multirow[t]{2}{*}{ Variable or risk factors } & \multirow[t]{2}{*}{ Category } & \multicolumn{2}{|c|}{$\begin{array}{c}\text { Campylobacter } \\
\text { isolation from the farm }\end{array}$} \\
\hline & & Positive & Negative \\
\hline \multirow[t]{2}{*}{ Stocking density (Birds/m2) } & $\leq 6$ & 0 & 9 \\
\hline & $>6$ & 21 & 5 \\
\hline \multirow[t]{2}{*}{ Distance between farms (m) } & $<1000$ & 21 & 0 \\
\hline & $\geq 1000$ & 0 & 14 \\
\hline \multirow[t]{2}{*}{ Decontamination of vehicles outside the farm } & Yes & 1 & 7 \\
\hline & No & 20 & 7 \\
\hline \multirow{2}{*}{ Fence (1.8 meter height) with secure gait } & Yes & 0 & 6 \\
\hline & No & 21 & 8 \\
\hline \multirow[t]{2}{*}{ Hand-washing before entering farm/house } & Yes & 3 & 3 \\
\hline & No & 18 & 3 \\
\hline \multirow{2}{*}{ Changing disinfectant in the pool } & Yes & 8 & 14 \\
\hline & No & 13 & 0 \\
\hline \multirow[t]{2}{*}{ Disinfection at house door } & Yes & 8 & 14 \\
\hline & No & 13 & 0 \\
\hline \multirow[t]{2}{*}{ Restricted access of vehicle and non-essential visitors } & Yes & 1 & 14 \\
\hline & No & 20 & 0 \\
\hline \multirow[t]{2}{*}{ Presence of disinfectant in the pool at farm gait } & Yes & 1 & 7 \\
\hline & No & 20 & 7 \\
\hline \multirow[t]{2}{*}{ Piles of litter inside the farm } & Yes & 10 & 0 \\
\hline & No & 11 & 14 \\
\hline \multirow[t]{2}{*}{ Presence of rodents (mice and rats) } & Yes & 2 & 4 \\
\hline & No & 19 & 10 \\
\hline \multirow[t]{2}{*}{ Presence of sparrows or pigeons } & Yes & 13 & 0 \\
\hline & No & 8 & 14 \\
\hline \multirow[t]{2}{*}{ Biweekly changing the pool disinfectant } & Yes & 1 & 7 \\
\hline & No & 20 & 7 \\
\hline \multirow{2}{*}{ Protective boots } & Yes & 3 & 14 \\
\hline & No & 18 & 0 \\
\hline \multirow[t]{2}{*}{ Sanitation/room facility } & Yes & 7 & 11 \\
\hline & No & 14 & 3 \\
\hline
\end{tabular}

a sanitizer when the $\mathrm{pH}$ of the water is neutral or acidic. In here, the mean values of the $\mathrm{pH}$ of drinkers of positive and negative farms are 7.38 and 7.51 respectively. Data are summarized in Table 1.

One limitation of this study is the limited number of farms studied. The study farms were the only available farms in the region during the study period. In Jordan, there are no integrated layer companies and their production is mostly dependent on individual layer farmers.

The significance of the study reported here is being new efforts conducted in layer farms to determine the prevalence rate and characterize isolation of Campylobacter and highlight important risk factors for their occurrence in layer farms.

The authors believe that the finding presented here is still relevant despite the lack of finding significant association between the evaluated risk factors and the isolation of Campylobacter in layer farms. It is recommended to improve hygienic practices at layer farms and to establish national guidelines and biosecurity standards to decrease prevalence rate of Campylobacter in layer farms which would positively impact the poultry industry and lower infection rate of human Campylobacter.

\section{References}

1. Sahin O, Morishita TY, Zhang Q. Campylobacter colonization in poultry: sources of infection and modes of transmission. Anim Health Res Rev 2002;3:95-105.

2. Sommer HM, Heuer OE, Sørensen AIV, Madsen M. Analysis of factors important for the occurrence of Campylobacter in Danish broiler flocks. Prev Vet Med 2013;111:100-11.

3. Mead PS, Slutsker L, Dietz V, et al. Food-related illness and death in the United States. Emerg Infect Dis 1999;5:607-25.

4. Nichols GL, Richardson JF, Sheppard SK, et al. Campylobacter epidemiology: a descriptive study reviewing 1 million cases in England and Wales between 1989 and 2011. BMJ Open 2012;2.

5. Denis F. [Diagnosis and control of human food poisoning outbreaks]. Bull Académie Natl Médecine 2012;196:1673-9. [Article in French].

6. Sorvillo FJ, Lieb LE, Waterman SH. Incidence of campylobacteriosis among patients with AIDS in Los Angeles County. J Acquir Immune Defic Syndr 1991;4:598-602.

7. Nowsad AA, Kanoh S, Niwa E. 
Thermal gelation characteristics of breast and thigh muscles of spent hen and broiler and their surimi. Meat Sci 2000;54:169-75.

8. Osaili TM, Alaboudi AR, Al-Akhras RR. Prevalence and antimicrobial susceptibility of Campylobacter spp. in live and dressed chicken in Jordan. Foodborne Pathog Dis 2012;9:54-8.

9. Al-Natour MQ, Alaboudi AR, Osaili TM, Obaidate MM. Resistance of Campylobacter jejuni Isolated from Layer Farms in Northern Jordan Using Microbroth Dilution and Disc Diffusion Techniques. J Food Sci 2016;81 :M1749-53.

10. ISO FDIS 102721. Microbiology of food and animal feeding. stuffs Horizontal method for detection and enumeration of Campylobacter spp. Part 1: detection method. International Organization for Standardization (ISO). 2006.

11. Hunt JM, Abeyta C, and Tran T. Isolation of campylobacter species from food and water. In: Bacteriological Analytical Manual. (BAM) 2001. http://www.fda.gov/Food/FoodScience Research/LaboratoryMethods/ucm0726 16.htm

12. Nayak R, Stewart TM, Nawaz MS. PCR identification of Campylobacter coli and Campylobacter jejuni by partial sequencing of virulence genes. Mol Cell Probes 2005;19:187-93.

13. Humphrey T, O'Brien S, Madsen M. Campylobacters as zoonotic pathogens: a food production perspective. Int $\mathrm{J}$ Food Microbiol 2007;117:237-57.

14. Newell DG, Elvers KT, Dopfer D, et al. Biosecurity-based interventions and strategies to reduce Campylobacter spp. on poultry farms. Appl Environ Microbiol 2011;77:8605-14.
15. Pearson AD, Greenwood M, Healing TD, et al. Colonization of broiler chickens by waterborne Campylobacter jejuni. Appl Environ Microbiol 1993;59:987-96.

16. Byrd JA, Corrier DE, Hume ME, et al. Effect of feed withdrawal on Campylobacter in the crops of marketage broiler chickens. Avian Dis 1998;42:802-6.

17. Byrd JA, Corrier DE, Hume ME, et al. Incidence of Campylobacter in crops of preharvest market-age broiler chickens. Poult Sci 1998;77:1303-5.

18. Ring M, Zychowska MA, Stephan R. Dynamics of Campylobacter spp. spread investigated in 14 broiler flocks in Switzerland. Avian Dis 2005;49:3906.

19. Berndtson E, Danielsson-Tham ML, Engvall A. Campylobacter incidence on a chicken farm and the spread of Campylobacter during the slaughter process. Int $\mathrm{J}$ Food Microbiol 1996;32:35-47.

20. Berndtson E, Tivemo M, Engvall A. Distribution and numbers of Campylobacter in newly slaughtered broiler chickens and hens. Int J Food Microbiol 1992;15:45-50.

21. Callicott KA, Friethriksdóttir V, Reiersen J, et al. Lack of evidence for vertical transmission of Campylobacter spp. in chickens. Appl Environ Microbiol 2006;72:5794-8.

22. Kapperud G, Skjerve E, Vik L, et al. Epidemiological investigation of risk factors for campylobacter colonization in Norwegian broiler flocks. Epidemiol Infect 1993;111:245-55.

23. Bouwknegt $M$, van de Giessen AW, Dam-Deisz WDC, et al. Risk factors for the presence of Campylobacter spp. in Dutch broiler flocks. Prev Vet Med
2004;62:35-49.

24. McDowell SWJ, Menzies FD, McBride $\mathrm{SH}$, et al. Campylobacter spp. in conventional broiler flocks in Northern Ireland: epidemiology and risk factors. Prev Vet Med 2008;84:261-76.

25. Ansari-Lari M, Hosseinzadeh S, Shekarforoush SS, et al. Prevalence and risk factors associated with campylobacter infections in broiler flocks in Shiraz, southern Iran. Int J Food Microbiol 2011;144:475-9.

26. Ellis-Iversen J, Jorgensen F, Bull S, et al. Risk factors for Campylobacter colonisation during rearing of broiler flocks in Great Britain. Prev Vet Med 2009;89:178-84.

27. Amaral L. Drinking water as a risk factor to poultry health. Rev Bras Ciênc Avícola 2004;6:191-9.

28. Line JE. Campylobacter and Salmonella populations associated with chickens raised on acidified litter. Poult Sci 2002;81:1473-7.

29. Line JE. Influence of relative humidity on transmission of Campylobacter jejuni in broiler chickens. Poult Sci 2006;85:1145-50.

30. Kalupahana RS, Kottawatta KSA, Kanankege KST, et al. Colonization of Campylobacter spp. in broiler chickens and laying hens reared in tropical climates with low-biosecurity housing. Appl Environ Microbiol 2013;79:3935.

31. Genigeorgis C, Hassuneh M, Collins P. Campylobacter Jejuni infection on poultry farms and its effect on poultry meat contamination during slaughtering. J Food Prot 1986;49:895-903. 